\title{
POTENTIAL OF FABRICATION OF DURIAN SKIN FIBER BIOCOMPOSITES FOR FOOD PACKAGING APPLICATION THROUGH THE ELECTRICITY IMPACT ANALYSIS
}

\author{
HAZleEN ANUAR ${ }^{1 *}$, Siti MUNiRAH SAlimah ABD RASHID ${ }^{1,}$ \\ Nurfarahin MOHD Nordin ${ }^{1}$, FATHILAH Ali ${ }^{2}$, YOSE FACHMI BUYs ${ }^{3}$, \\ SABU ThOMAS ${ }^{4}$, NUR AIMI MOHD NASIR ${ }^{1}$ AND \\ SYAZEVEN EFFATIN AZMA MOHD ASRI ${ }^{1}$ \\ ${ }^{I}$ Department of Manufacturing and Materials Engineering, \\ ${ }^{2}$ Department of Biotechnology Engineering, \\ Kulliyyah of Engineering, International Islamic University Malaysia, \\ Jalan Gombak, 53100 Kuala Lumpur, Malaysia \\ ${ }^{3}$ Department of Mechanical Engineering, Faculty of Engineering, \\ University of Malaya, 50603 Kuala Lumpur, Malaysia \\ ${ }^{4}$ School of Energy Materials and International and Inter University Centre for Nanoscience \\ and Nanotechnology, Mahatma Gandhi University, Priyadarshini Hills, \\ Kottayam 686560, Kerala, India \\ *Corresponding author: hazleen@iium.edu.my
}

(Received: $2^{\text {nd }}$ November 2020; Accepted: $17^{\text {th }}$ March 2021; Published on-line: $4^{\text {th }}$ July 2021)

\begin{abstract}
As an effort to replace the petroleum-based polymers and reduce wasterelated environmental problems, biopolymers are the best candidate due to their renewable, biodegradable and commercially viable. Initiative have been taken by developing durian skin fibre (DSF) reinforced polylactic acid (PLA) biocomposites with the addition of epoxidized palm oil (EPO). PLA/DSF biocomposites were fabricated via extrusion and then injection moulded. The biocomposites were assessed for its life cycle by developing a system boundary related to its fabrication processes using $\mathrm{GaBi}$ software. The life cycle assessment (LCA) of PLA/DSF biocomposites show that global warming potential (GWP) and acidification potential (AP) were the major impacts from PLA/DSF biocomposite. For PLA/DSF biocomposite, the results were $199.37 \mathrm{~kg} \mathrm{CO}_{2}$ equiv. GWP and $0.58 \mathrm{~kg} \mathrm{SO}_{2}$ equiv. AP. Meanwhile, for PLA/DSF/EPO biocomposite, the results obtained were $195.89 \mathrm{~kg} \mathrm{CO}_{2}$ equiv. GWP and $0.57 \mathrm{~kg} \mathrm{SO}_{2}$ equiv. AP. The GWP and AP were contributed by the electricity used in the fabrication of biocomposites. These impacts were due to the usage of electricity, which contributed to the emission of $\mathrm{CO}_{2}$. However, the PLA/DSF/EPO biocomposite had lower negative impacts because EPO improved the workability and processability of the biocomposite, and hence, reduced the amount of energy required for production. It can be concluded that the plasticized PLA/DSF biocomposite can be a potential biodegradable food packaging material as it has favourable properties and produces no waste.
\end{abstract}

ABSTRAK: Biopolimer adalah terbaik dalam usaha mengganti polimer berasaskanpetroleum dalam mengurang masalah pencemaran-sisa. Ini kerana biopolimer boleh diperbaharui, biodegradasi dan sangat maju secara komersial. Inisiatif telah diambil dengan menghasilkan sabut kulit durian (DSF) bersama biokomposit asid polilaktik (PLA) dengan penambahan minyak kelapa sawit terepoksi (EPO). Biokomposit PLA/DSF direka melalui kaedah pemyemperitan dan acuan suntikan. Biokomposit ini 
dipantau kitar hidupnya dengan membina sistem sempadan berkaitan proses rekaan menggunakan perisian GaBi. Pengawasan kitar hidup (LCA) biokomposit PLA/DSF menunjukkan potensi pemanasan global (GWP) dan potensi pengasidan (AP) menyebabkan impak terbesar komposit PLA/DSF. Dapatan kajian menunjukkan 199.37 $\mathrm{kg} \mathrm{CO}_{2}$ bagi GWP dan $0.58 \mathrm{~kg} \mathrm{SO}_{2}$ bagi AP bagi biokomposit PLA/DSF. Sementara itu, dapatan kajian bagi biokomposit PLA/DSF/EPO adalah $195.89 \mathrm{~kg} \mathrm{CO}_{2}$ bagi GWP dan $0.57 \mathrm{~kg} \mathrm{SO} \mathrm{SO}_{2}$ bagi AP. Kedua-dua GWP dan AP adalah disebabkan oleh penggunaan elektrik dalam proses pembuatan biokomposit. Ini adalah kesan daripada penggunaan elektrik, dan menyumbang kepada pembebasan $\mathrm{CO}_{2}$. Walau bagaimanapun, biokomposit PLA/DSF/EPO mempunyai kurang kesan negatif, kerana EPO telah menambah baik kebolehkerjaan dan kebolehprosesan biokomposit, menyebabkan kurang tenaga yang diperlukan dalam proses pembuatan. Kesimpulannya plastik biokomposit PLA/DSF berpotensi sebagai bahan biodegradasi bagi pembungkus makanan kerana ianya mempunyai ciri-ciri yang diperlukan dan tidak menghasilkan sisa buangan.

KEYWORDS: life cycle assessment; cradle-to-grave; durian skin fibre; plasticizer; food packaging; polylactic acid

\section{INTRODUCTION}

Earth has ecosystem that consists of humans, plant life, ocean and natural resources. However, the development of engineering has resulted in resource depletion and environmental destruction. Almost all food packaging including single use packaging are petroleum-based polymers that are undegradable in nature and when they are being dumped on the land and in the ocean; it leads to the production of smelly garbage or polluted water. These problems are crucial environmental issues that should not be taken lightly.

Food packaging provide protection to the food, to maintain the quality and safety of the food from the environment and other physical harm. Food packaging is important when transporting the food from one place to another [1]. Most food packaging is made from glass, cloth, metal, paper and polymers. Polymers are the most common materials used in the food packaging industry due to their superior properties.

The most commonly used plastics in packaging include polyethylene terephthalate (PET), polyvinyl chloride (PVC), polyethylene (PE), polypropylene (PP), polystyrene (PS) and polyamide [2,3]. The utilization of these polymers harms the environment and ecosystems via global warming and ozone layer depletion. This is due to the unwanted gas like carbon dioxide is released to the atmosphere. The degradation process of polymers takes many years to be completed. PP for example shows resistance to biodegradation since it is highly hydrophobic, high molecular weight, lacks an active functional group and has a continuous chain of repetitive methylene units [4].

\section{METHODOLOGY}

The framework was conducted according to ISO 14040 [5] and ISO 14044 [6] which involve four phases; goal and scope definition, inventory analysis, impact assessment and interpretation using $\mathrm{GaBi}$ software.

\subsection{Goal and Scope Definition}

The goal of this study is to assess the environmental impacts of food packaging made of PLA/DSF in comparison with PLA/DSF with the addition of epoxidized palm oil (EPO) as a plasticizer. This comparison was to investigate the effect of EPO on PLA/DSF 
on the environmental impact. The functional unit of this study was 50-unit biodegradable food packaging and the reference flow was $850 \mathrm{~g}$ for each PLA/DSF and PLA/DSF/EPO biocomposite. The scope of this study was from the preparation of durian skin fibre, preparation of biocomposite and fabrication of biocomposite into food packaging before end-of-life disposal. The scope of impact assessment covered was global warming, acidification, eutrophication and ozone depletion. These impacts were chosen based on the impact on electricity usage as electricity was the main contributor and this could be the main cause for the climate change. The study covered the entire life cycle of PLA/DSF and PLA/DSF/EPO biocomposite from cradle-to-grave.

\subsection{System Boundary}

The system boundary in this study includes the preparation of DSF, manufacturing of biocomposites and end-of-life stage. The preparation of DSF involves chopping and grinding, washing, drying and alkali treatment process while manufacturing of biocomposite covers extrusion and injection moulding. The inputs and outputs of each biocomposite food packaging manufacturing process was identified based on the inventory analysis elaborated later. From the information gathered in the inventory analysis, system boundaries for both biocomposites were determined. Figures 1 and 2 show the schematic diagrams of input and output flow for PLA/DSF and PLA/DSF/EPO biocomposites, respectively.

\subsection{Data Sources and Limitations}

In this study, the input and output data for preparation of DSF and fabrication of biocomposites were primary data which was collected during the process. The covered data consists of raw material (durian skin waste) and energy consumption for the fabrication of biocomposite. Data on production of PLA resin and EPO was excluded as these two materials were bought from the supplier and delivered directly to the fabrication lab. The use phase also was neglected as this biocomposite still in prototype food packaging.

\subsection{Inventory Analysis}

The inventory analysis was gathered which include the material and energy inputs, air emissions, solid waste emissions and waterbone emissions in the life cycle of the PLA/DSF biocomposite with and without EPO. It involved collecting quantitative data for every unit process in the system based on a functional unit of product. Details of each phase starting from durian skin fibre preparation until end-of-life stage are explained next.

\subsection{Raw Materials}

Durian skins waste were collected from local markets and transported to IIUM. PLA (grade 3052) was obtained from NatureWorks, China; EPO was obtained from Malaysian Palm Oil Board; and databases for raw PLA and EPO were obtained from GaBi software (which were compiled from a literature review by [7-10] for EPO. The database for PLA was obtained from a study by [11]. The composition of the biocomposite was observed based on the weight of the food packaging. The biocomposite was initially prepared for $1000 \mathrm{~g}$ including waste after injection moulded. From such preparation, the weight of a single food packaging was determined at $17 \mathrm{~g}$ whereas the total weight for 50 units of biocomposite food packaging was $850 \mathrm{~g}$. Compositions for each PLA are shown in Tables 1 and 2. 
Table 1: Composition of PLA/DSF biocomposite

\begin{tabular}{cccc}
\hline Material & $\begin{array}{c}\text { Composition } \\
(\%)\end{array}$ & $\begin{array}{c}\text { Weight } \\
\text { for } \mathbf{1} \\
\text { unit }(\mathbf{g})\end{array}$ & $\begin{array}{c}\text { Weight for } \\
\mathbf{5 0} \text { units }(\mathbf{g})\end{array}$ \\
\hline PLA & 70 & 11.9 & 595 \\
DSF & 30 & 5.1 & 255 \\
Total & 100 & 17 & 850 \\
& & & \\
\hline
\end{tabular}

Table 2: Composition of

PLA/DSF/EPO biocomposite

\begin{tabular}{cccc}
\hline Material & $\begin{array}{c}\text { Composition } \\
(\boldsymbol{\%})\end{array}$ & $\begin{array}{c}\text { Weight } \\
\text { for } \mathbf{1} \\
\text { unit }(\mathbf{g})\end{array}$ & $\begin{array}{c}\text { Weight } \\
\text { for 50 } \\
\text { units }(\mathbf{g})\end{array}$ \\
\hline PLA & 65 & 11.05 & 552.5 \\
DSF & 30 & 5.1 & 255 \\
EPO & 5 & 0.85 & 42.5 \\
Total & 100 & 17 & 850 \\
\hline
\end{tabular}

\subsection{Preparation of Durian Skin Fibre (DSF)}

The durian skin was cut into smaller pieces and washed thoroughly with tap water to remove any dust and adhering particles. The skin was then dried at $70{ }^{\circ} \mathrm{C}$ for $24 \mathrm{~h}$. The dried skin was ground to obtain fibre with 100 to $150 \mu \mathrm{m}$ in length. The weight of the raw durian skin fibres used is approximately $300 \mathrm{~g}$. Sodium hydroxide $(\mathrm{NaOH})$ was used for alkali treatment of DSF.

\subsection{Preparation of Biocomposites}

Next, fabrication process of the biocomposite consists of extrusion using extruder (Brabender, Germany) and injection moulding processes using Battenfeld HM 600/850 injection moulding machine. The temperature profile from barrel to die was $160{ }^{\circ} \mathrm{C}$ to 170 ${ }^{\circ} \mathrm{C}$ at $100 \mathrm{rpm}$ screw speed. For injection moulding, the temperature was $165^{\circ} \mathrm{C}$ to $180{ }^{\circ} \mathrm{C}$ for all four zones of the injection moulding machine and $45 \mathrm{~s}$ cooling time. Finally, the biocomposite food packaging waste was exposed to the environment for end-of-life stage.

\subsection{Transportation}

Transportation is referring to picking up the waste durian skins from Petaling Jaya, to laboratory at Gombak, Selangor, Malaysia. Transportation data required for conveying the product to the end user and to the transfer station was not available, because the process is assumed to have only evolved within the area of fabrication, which is IIUM. The total journey from IIUM Gombak to Petaling Jaya and back to IIUM Gombak is approximately $92 \mathrm{~km}$. The transportation for obtaining the PLA and EPO were not included in this study since it was delivered to IIUM. Both PLA/DSF biocomposites were still in prototype, thus the distribution of the biocomposites to the consumer was not included for transportation.

\subsection{Electricity}

Table 3 describes the total power and electricity utilized for each particular process in the production of PLA/DSF and PLA/DSF/EPO biocomposites.

Table 3: Power calculation of each machine used.

\begin{tabular}{cccc}
\hline Machine & $\begin{array}{c}\text { Total time utilised for } \\
\mathbf{5 0} \text { units (hours) }\end{array}$ & $\begin{array}{c}\text { Total power } \\
(\mathbf{k W h})\end{array}$ & $\begin{array}{c}\text { Energy } \\
(\mathbf{M J})\end{array}$ \\
\hline Oven & a) 24 & a) 36 & a) 129.6 \\
& b) 48 & b) 72 & b) 259.2 \\
Extruder & 10 & 50 & 180 \\
Grinder & 0.85 & 3.4 & 12.24 \\
Injection & 1.25 & 66.94 & 240.98 \\
moulding & & & \\
\hline
\end{tabular}




\subsection{End-of-Life Stage}

The PLA/DSF and PLA/DSF/EPO biocomposite were exposed to the environment to observe their degradation time. Both biocomposites took about five to six months to fully biodegrade.

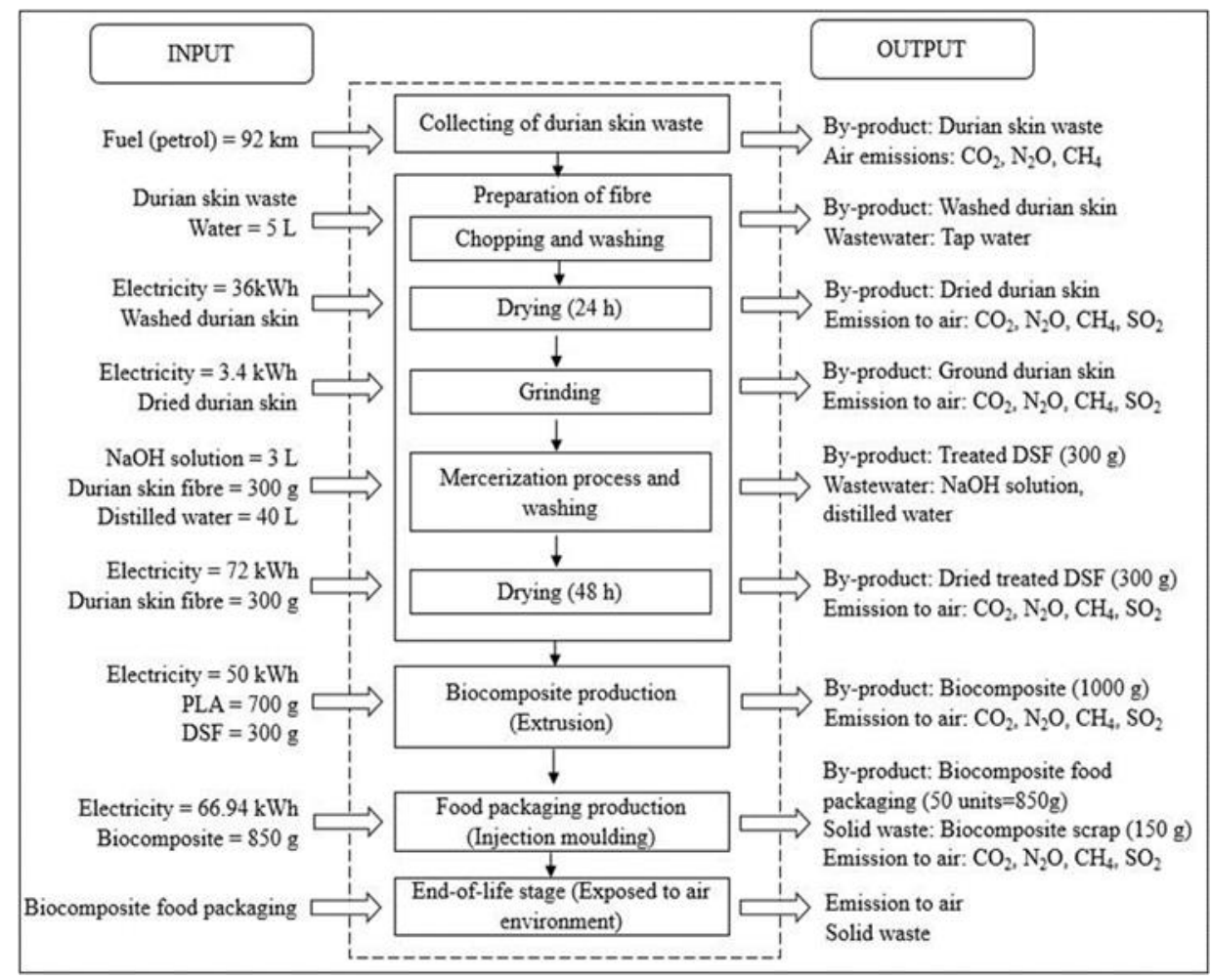

Fig. 1: System boundary of PLA/DSF biocomposite.

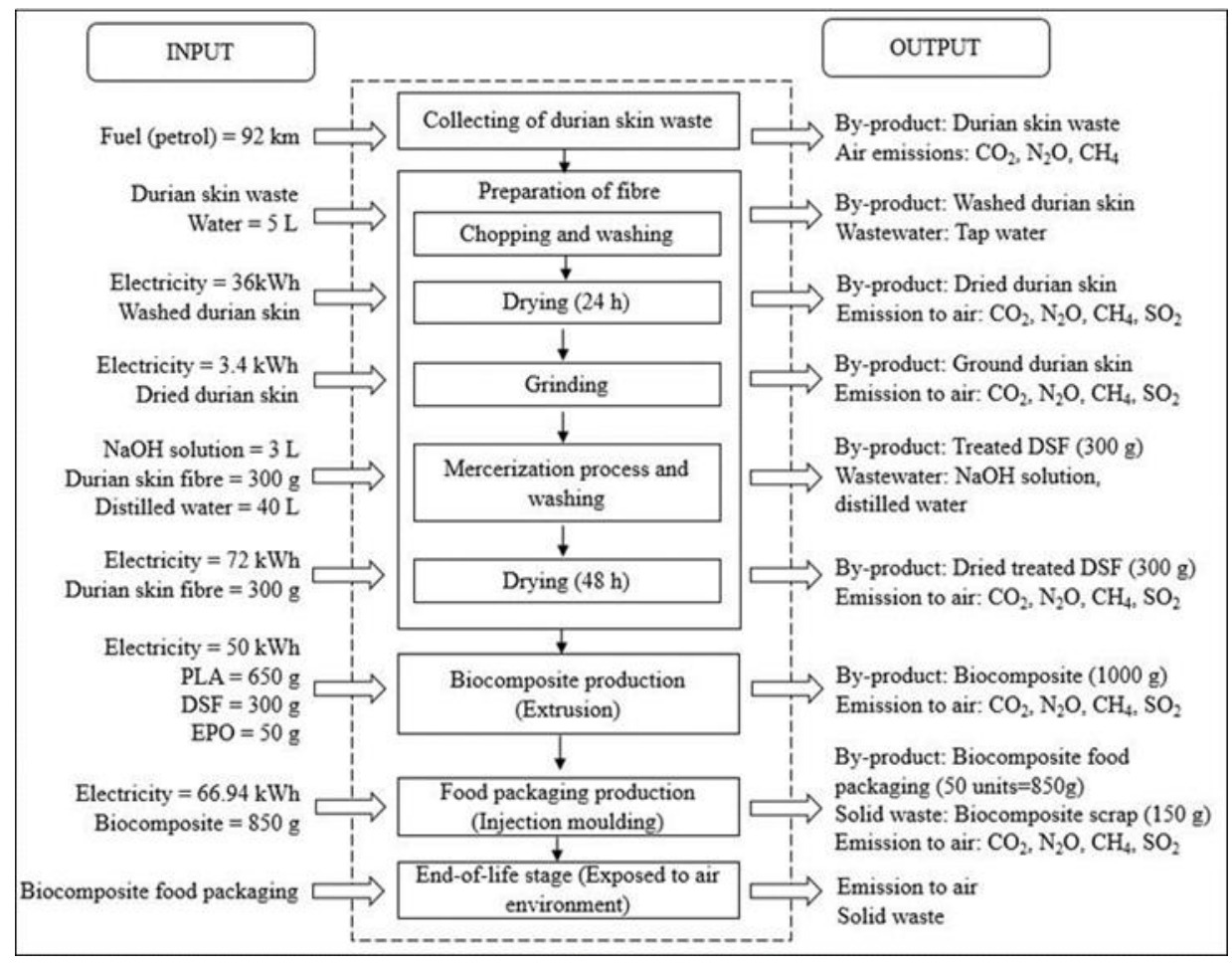

Fig. 2: System boundary of PLA/DSF/EPO biocomposite. 


\subsection{Impact Assessment}

The environment impact assessment was conducted to evaluate and analyse the possibility of activities in the inventory analysis and production of biocomposite food packaging whether to leave negative environmental impacts on the earth or not. For this examination, effects were measured up to the midpoint level. The midpoint level expects to cover ecological issues that stand close to the inventory and endpoint results. Ecological impact categories, under the midpoint level, include carbon footprint, photochemical ozone formation, human toxicity, water footprint, ozone layer depletion, global warming, acidification, eutrophication, etc., depend on the Intergovernmental Panel on Climate Change (IPCC). Among the impact listed, the last four contributed to the highest impact score and play a vital role in the lifecycle of PLA/DSF biocomposite food containers. This study uses the ReCiPe (1.08) Life Cycle Impact Assessment (LCIA) method, run through $\mathrm{GaBi}$ software, and based on ISO 14040 framework [5] and ISO 14044-guidelines and requirements [6].

\section{RESULTS AND DISCUSSION}

The results are analysed for four major environmental impacts comprised of global warming potential, ozone layer depletion potential, acidification potential and eutrophication potential based on the impact in electricity usage as this could be the main cause for climate change. The environmental impacts evaluated was cradle-to-grave analysis started from raw materials, processing, manufacturing and end life of the product which was landfill. Based on the impact score, global warming potential (GWP) possesses the highest impact score with $199.38 \mathrm{~kg} \mathrm{CO}_{2}$ equiv. for PLA/DSF over PLA/DSF/EPO with $195.89 \mathrm{~kg} \mathrm{CO}$ equiv. These are followed by acidification potential (AP), with an impact score of $0.58 \mathrm{~kg} \mathrm{SO} 2$ equiv. for PLA/DSF and $0.57 \mathrm{~kg} \mathrm{SO}_{2}$ equiv. for PLA/DSF/EPO. The remaining two impacts considered in this study produced very low values of impact score; which are deemed insignificant. For all four impacts considered in this study, PLA/DSF showed a higher potential of environmental impacts than PLA/DSF/EPO biocomposites. This was as expected as biocomposite consists of EPO that is bio-based and environmentally friendly plasticizer. According to [12], plasticizers made from natural sources incorporated into a bio-based polymer provide lower negative impacts to the environment.

\subsection{Global Warming Potential (GWP)}

The findings for global warming potential (GWP) are presented in Table 4 and Fig. 3 as percentage values. From Table 4 and Fig. 3, it can be seen that the injection moulding process had the highest contribution towards the global warming potential for both biocomposites. The process of PLA/DSF showed a slightly higher percentage, at $33.08 \%$ over PLA/DSF/EPO at $31.70 \%$. Plasticizer, added to the composites, improved their workability, processability and flexibility, making them easier to be processed with reduced energy needed [13]. Therefore, the percentage contribution of each biocomposites process towards GWP was different as EPO was added at the beginning of the mixing process for the plasticized one.

Figure 3 clearly shows that the major contributors towards GWP are the drying, mixing and injection moulding processes of both biocomposites. These processes contribute up to $95.0 \%$ of the total GWP for both PLA/DSF and PLA/DSF/EPO biocomposites. Specifically, these processes require electricity to generate output (i.e., biocomposite food packaging). Consumption of electricity highly contributed towards the 
release of $\mathrm{CO}_{2}$ gas. Energy industries are a major source of greenhouse gases in Malaysia $[14,15]$. Global warming is mainly caused by the release of greenhouse gases into the environment; primarily $\mathrm{CO}_{2} . \mathrm{CO}_{2}$ emissions take up to $93.0 \%$ and the rest are other greenhouse gases, such as nitrous oxide and methane. [16] stated that the three crucial sources of fossil fuel, that highly affected the power generation operations in Malaysia are natural gas, coal fuel and hydropower. However, hydropower that come from renewable energy sources used only small percentage as compared to other sources. Emissions of greenhouse gases, mainly $\mathrm{CO}_{2}$ from the burning of fossil fuels, cause environmental degradation and global warming. Therefore, the more electricity utilised in the production of biocomposites raises the emission level of $\mathrm{CO}_{2}$ gas to the environment; eventually contributing towards global warming. The amount of electricity used are high in the fabrication process due to the utilisation of various machines.

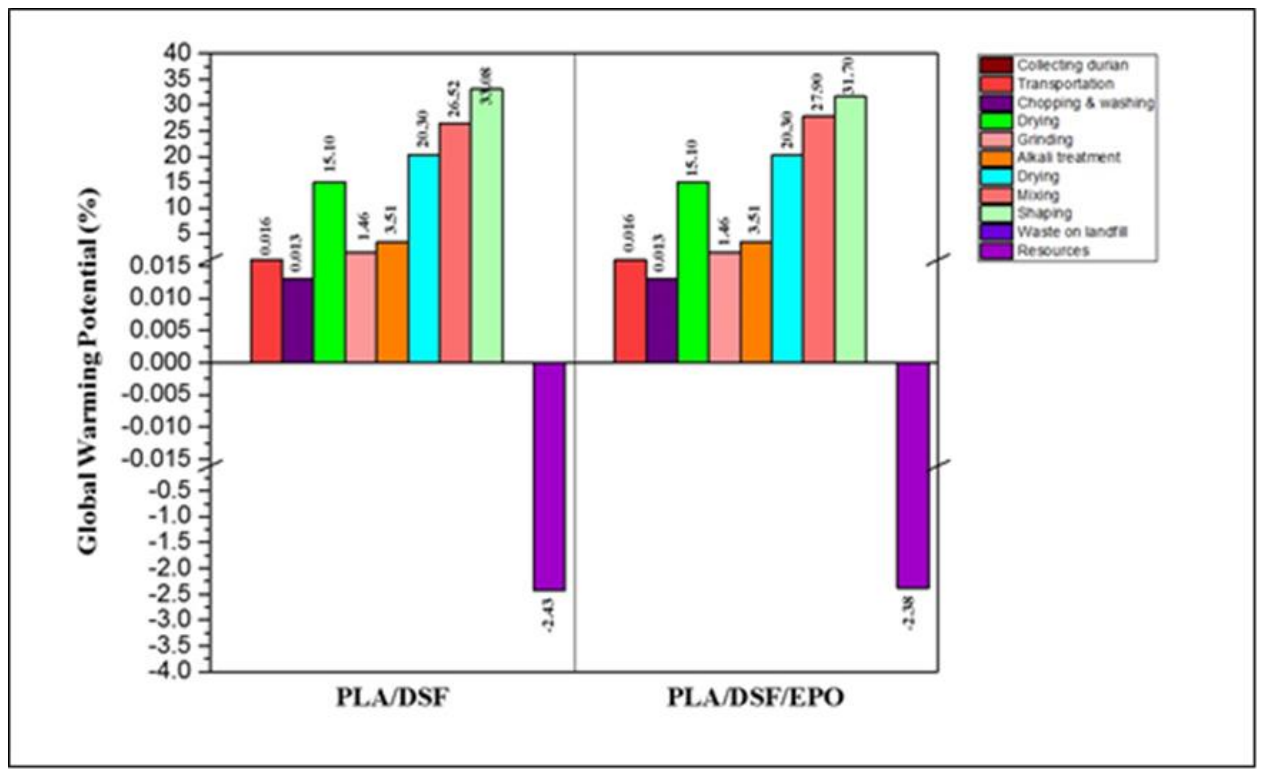

Fig. 3: Percentage contribution of each process to GWP.

Table 4: Percentage contribution of each process to GWP

\begin{tabular}{ccc}
\hline Process & \multicolumn{2}{c}{$\begin{array}{c}\text { of GWP for each process } \\
\text { (kg CO2 equiv.) }\end{array}$} \\
\cline { 2 - 3 } & PLA/DSF & PLA/DSF/EPO \\
\hline Collecting durian skin waste & 0 & 0 \\
Transportation & 0.016 & 0.016 \\
Chopping and washing & 0.013 & 0.013 \\
Drying (24 h) & 15.10 & 15.10 \\
Grinding & 1.46 & 1.46 \\
Alkali treatment & 3.51 & 3.51 \\
Drying (48 h) & 20.30 & 20.30 \\
Mixing (extrusion) & 26.52 & 27.90 \\
Shaping (injection moulding) & 33.08 & 31.70 \\
Waste on landfill & 0 & -2.38 \\
Recovery & -2.43 & \multicolumn{2}{c}{ (kg CO } \\
& Total GWP value of each type of biocomposite \\
& \multicolumn{2}{c}{ (Including material recovery) } \\
& 199.38
\end{tabular}


Meanwhile, the process of chopping and washing of durian skins contributed less to the potential global warming, about $0.013 \%$, for both biocomposites. This is because only tap water is used in the process and no greenhouse gases are emitted during fibre preparation. A previous study on environmental impact was done by [17] on tap water and compared with bottled mineral water. The study found that tap water imparted a lower environmental impact than bottled mineral water. In Fig. 3, the resource column indicates that resource recovery is involved in the production process. The biocomposites are produced from bio-based materials that originated from plants, such as DSF and PLA. Carbon dioxide can be sequestered, as plants consume it, even though it is released during the production process [18]. In summary, GWP for PLA/DSF/EPO contributed less to global warming than PLA/DSF biocomposite; with the potential of $195.89 \mathrm{~kg} \mathrm{CO} 2$ equiv. compared to $199.38 \mathrm{~kg} \mathrm{CO}_{2}$ equiv.

\subsection{Acidification Potential (AP)}

Table 5 and Fig. 4 present the percentage of acidification potential of each process involved in the production process of both biocomposites. From Table 5 and Fig. 4, the injection moulding process shows significantly high potential to acidification as compared to other process, which is responsible for $30.51 \%$ of AP from PLA/DSF biocomposite and $31.59 \%$ of AP from PLA/DSF/EPO biocomposite. Similarly, the major contributors to AP of both biocomposites are from the processes that need electricity, namely injection moulding, extrusion and drying. The acidification potential of these processes includes electricity generated $97.15 \%$ of total AP for PLA/DSF and $98.60 \%$ of total AP for PLA/DSF/EPO biocomposites including the grinding process. From the total AP for both biocomposites, more than $57 \%$ comes from the emission of nitrogen oxides, followed by sulfur dioxides at $41 \%$. A small portion is made up of ammonia and nitrogen dioxides. This is due to the utilization of electricity during biocomposites fabrication. The ocean and the atmosphere absorb the toxic gases generated and hence acidity is increased. As a conclusion, even though the contribution of electricity to AP for PLA/DSF/EPO is higher than PLA/DSF, the total AP of PLA/DSF/EPO is lower than that of PLA/DSF. Therefore, PLA/DSF/EPO causes less effect to the acidification as compared to PLA/DSF biocomposite.

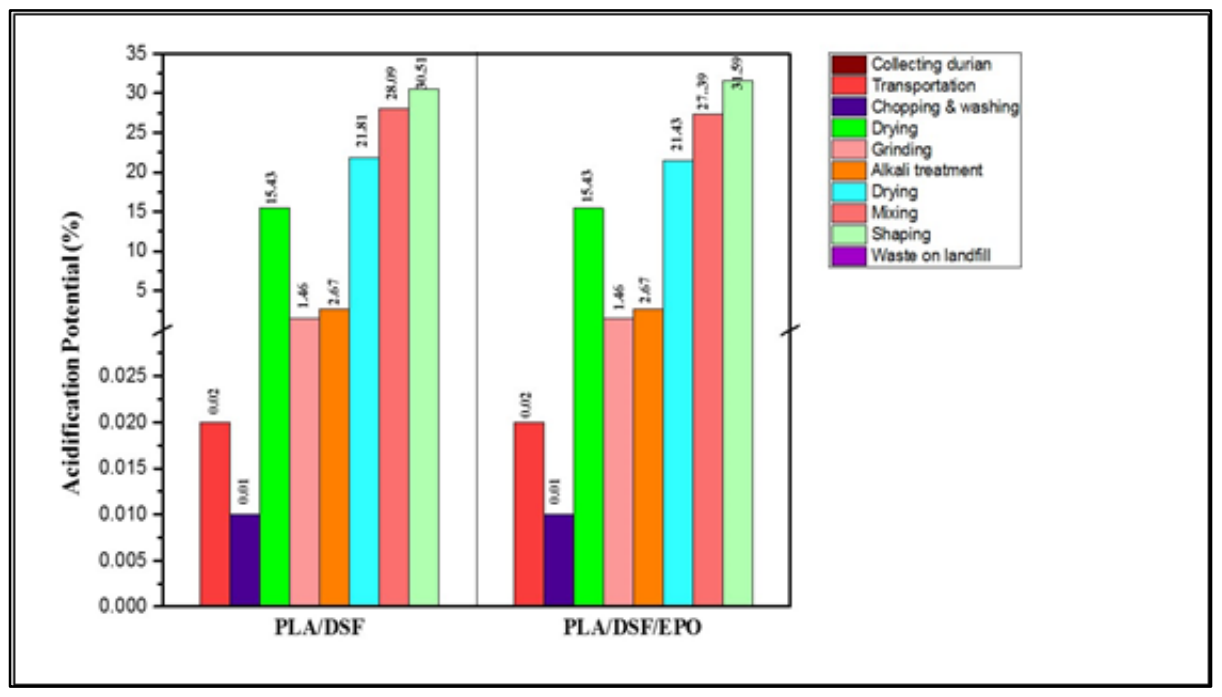

Fig. 4: Percentage contribution of each process to AP. 
Table 5: Percentage contribution of each process to AP

\begin{tabular}{ccc}
\hline Process & \multicolumn{2}{c}{$\begin{array}{c}\text { \% of AP for each process } \\
\text { (kg SO } \mathbf{S}_{2} \text { equiv.) }\end{array}$} \\
\cline { 2 - 3 } & PLA/DSF & PLA/DSF/EPO \\
\hline Collecting durian skin waste & 0 & 0 \\
Transportation & 0.02 & 0.02 \\
Chopping and washing & 0.01 & 0.01 \\
Drying (24 h) & 15.43 & 15.43 \\
Grinding & 1.46 & 1.46 \\
Alkali treatment & 2.67 & 2.67 \\
Drying (48 h) & 21.81 & 21.43 \\
Mixing (extrusion) & 28.09 & 27.39 \\
Shaping (injection moulding) & 30.51 & 31.59 \\
Waste on landfill & 0 & 0 \\
& Total AP value of each type of \\
& \multicolumn{2}{c}{ biocomposite } \\
& \multicolumn{2}{c}{ (kg SO $\mathrm{SO}_{2}$ equiv.) } \\
\hline \multicolumn{2}{c}{0.58} \\
\hline
\end{tabular}

\subsection{Eutrophication Potential (EP)}

Eutrophication is one of several environmental impacts considered in this study; and showed a very low impact score. Eutrophication is measured in terms of $\mathrm{kg} \mathrm{P}$ equiv. as it is mainly caused by phosphorus and phosphate [19]. The LCA leads to $8.29 \times 10^{-5} \mathrm{~kg} \mathrm{P}$ equiv. for PLA/DSF and $6.95 \times 10^{-5} \mathrm{~kg} \mathrm{P}$ equiv. for PLA/DSF/EPO. Table 6 and Fig. 5 indicate the results generated from the study for eutrophication potential. Figure 5 shows that the alkali treatment process for DSF displayed the highest potential to eutrophication; with $37.27 \%$ for both biocomposites. This process consumes sodium hydroxide, tap water and distilled water. The waste is then discharged through the sewage system before going directly into soil and water bodies, stimulates, and eventually causes eutrophication.

When the waste yielded from the alkali treatment process is discharged, it unlocks the phosphate and phosphorus contained within the soil; thus, increasing the nutrients level of the soil. When the concentration levels of the nutrients are too high, they are carried by rain water into rivers and ground waters that subsequently flow into lakes and seas. [20] assured that wastewater is a contributor for eutrophication to occur; where it increases the amount of nitrogen and phosphorus transferred to water bodies.

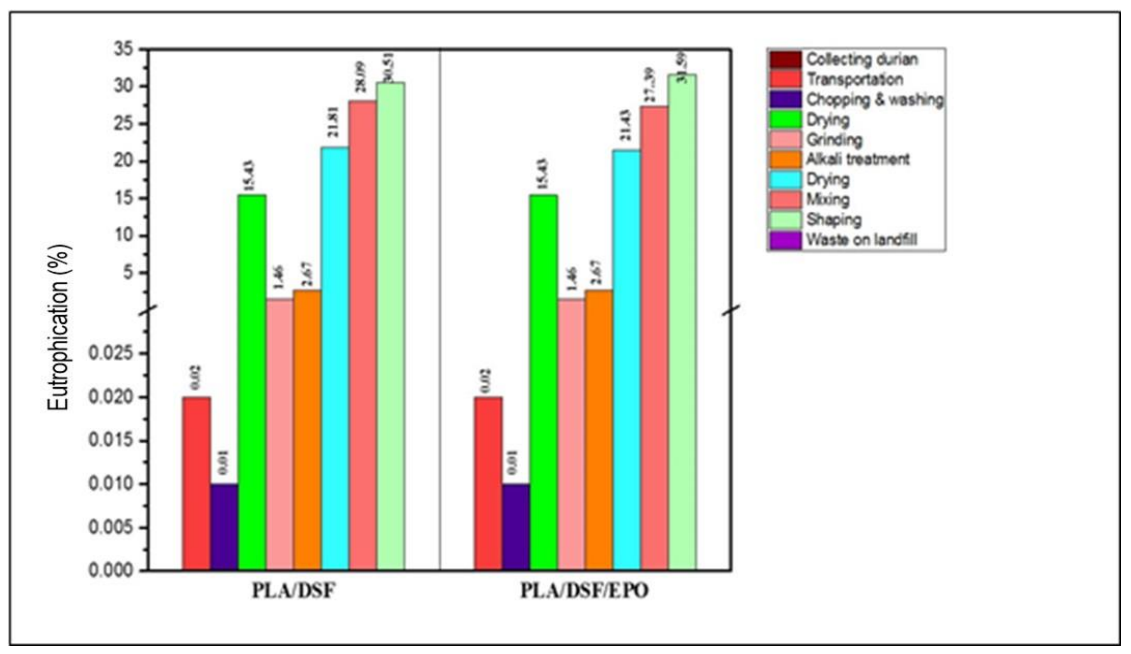

Fig. 5: Percentage contribution of each process to EP. 
Table 6: Percentage contribution of each process to EP

\begin{tabular}{ccc}
\hline Process & \multicolumn{2}{c}{$\begin{array}{c}\text { of EP for each process } \\
\text { (kg P equiv.) }\end{array}$} \\
\cline { 2 - 3 } & PLA/DSF & PLA/DSF/EPO \\
\hline Collecting durian skin waste & 0 & 0 \\
Transportation & 0.05 & 0.05 \\
Chopping and washing & 9.67 & 9.67 \\
Drying (24 h) & 2.53 & 2.53 \\
Grinding & 0.91 & 0.91 \\
Alkali treatment & 37.27 & 37.27 \\
Drying (48 h) & 16.16 & 16.16 \\
Mixing (extrusion) & 18.51 & 17.43 \\
Shaping (injection moulding) & 14.96 & 15.98 \\
Waste on landfill & 0 & 0 \\
& Total EP value of each type of \\
& \multicolumn{2}{c}{ biocomposite } \\
& \multicolumn{2}{c}{ (kg P equiv.) } \\
\hline
\end{tabular}

The transportation process contributes the lowest impact to eutrophication. This is because transportation does not produce waste that is discharged to soil and water bodies, but contributes towards other environmental impacts through emissions of gases into the air. In conclusion, eutrophication is not affected by the life cycle of the biocomposites based on the low impact score of EP which is nearly zero.

\subsection{Ozone Depletion Potential (ODP)}

Ozone layer depletion, or ozone depletion potential (ODP), for both biocomposites is further analysed and presented in Table 7 and Fig. 6. ODP is considered as the negligible impact on the biocomposites in this study. This is due to the lowest impact score obtained; which was nearly zero. ODP is the most insignificant impact from the food packaging industry. This is in agreement with a previous finding by [21] which showed that ODP yields a very low impact score compared to other environmental impacts.

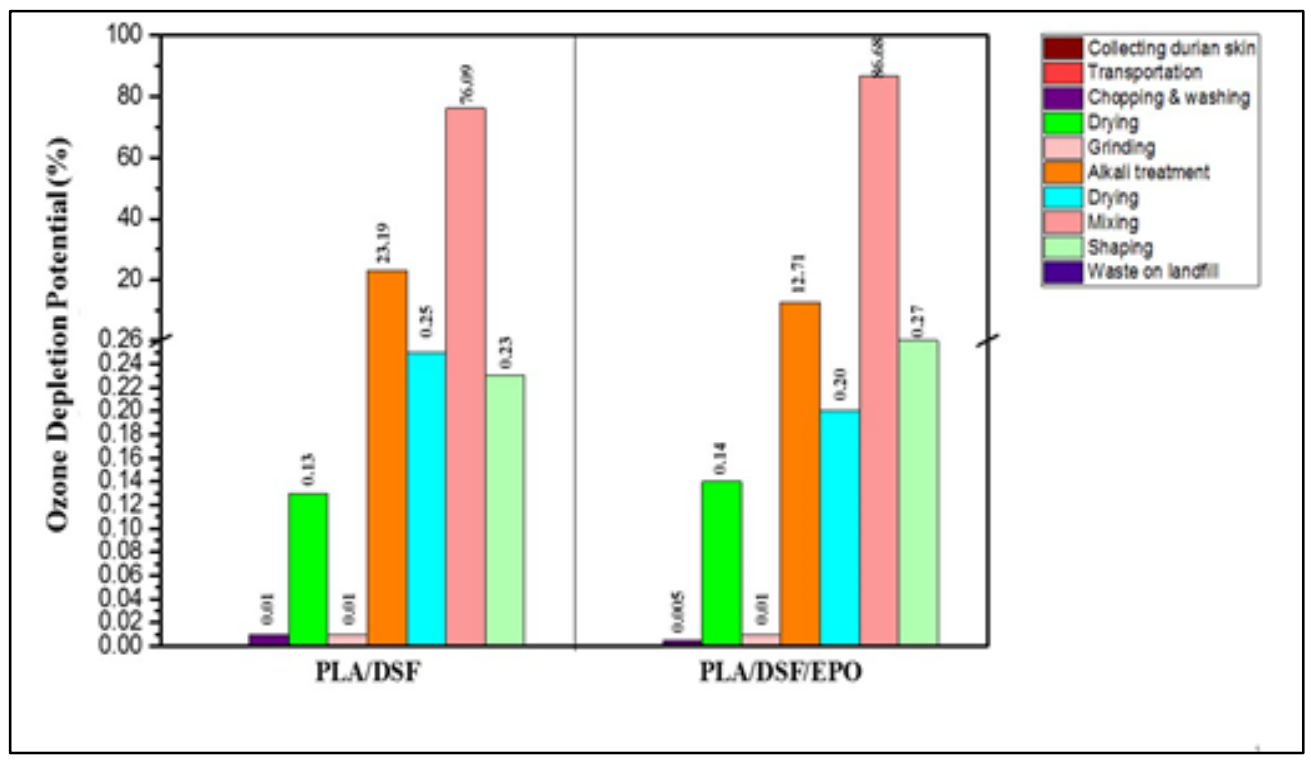

Fig. 6: Percentage contribution of each process to ODP. 
Table 7: Percentage contribution of each process to ODP

\begin{tabular}{|c|c|c|}
\hline \multirow[t]{2}{*}{ Process } & \multicolumn{2}{|c|}{$\begin{array}{l}\text { \% of ODP for each process } \\
\text { (kg CFC-11 equiv.) }\end{array}$} \\
\hline & PLA/DSF & PLA/DSF/EPO \\
\hline Collecting durian skin waste & 0 & 0 \\
\hline Transportation & 0 & 0 \\
\hline Chopping and washing & 0.01 & 0.005 \\
\hline Drying (24 h) & 0.13 & 0.14 \\
\hline Grinding & 23.19 & 12.71 \\
\hline Alkali treatment & 0.25 & 0.20 \\
\hline Drying (48 h) & 76.09 & 86.68 \\
\hline Mixing (extrusion) & 0.23 & 0.27 \\
\hline \multirow{4}{*}{$\begin{array}{l}\text { Shaping (injection moulding) } \\
\text { Waste on landfill }\end{array}$} & 0 & 0 \\
\hline & 0 & 0 \\
\hline & \multicolumn{2}{|c|}{$\begin{array}{l}\text { Total ODP value of each type of } \\
\text { biocomposite } \\
\text { (kg CFC-11 equiv.) }\end{array}$} \\
\hline & $8.28 \times 10^{-10}$ & $1.2810^{-10}$ \\
\hline
\end{tabular}

\section{CONCLUSION}

The fabrication of biocomposites food packaging causes significant global warming and acidification to occur. The impact scores are higher with almost $200 \mathrm{~kg} \mathrm{CO}_{2}$ equiv and $0.5 \mathrm{~kg} \mathrm{SO}_{2}$ equiv. PLA/DSF produced higher impact compared to PLA/DSF/EPO for all categories. GWP and AP were not significantly difference but for EP and ODP the impact difference between PLA/DSF and PLA/DSF/EPO was almost 19\%. This impact is due to generation of electricity throughout the production process. The highest emission was achieved by carbon dioxide with the highest percentage value. Ozone layer depletion and eutrophication potential values were very low, almost zero. Meanwhile, eutrophication only affected by the alkali process in the fabrication of biocomposites, which produces waste discharged into the soil and other water bodies.

\section{ACKNOWLEDGEMENT}

The authors wish to thank the Ministry of Higher Education (MOHE) Malaysia for the funding provided through the Fundamental Research Grant Scheme (FRGS/1/2019/TK05/UIAM/02/2), Research Initiative Grant Scheme-Post-Doctoral Fellow (RPDF18-010-0010) from the International Islamic University Malaysia (IIUM), Department of Science \& Technology (DST)-ASEAN-India Research Training Fellowship (RTF/2019/000083) for the equipment and facilities provided in making these studies a success.

\section{REFERENCES}

[1] Duncan TV. (2011) Applications of nanotechnol. in food packaging and food safety: barrier materials, antimicrobials and sensors. J. of Colloid and Interface Science, 363: 1-24. https://doi.org/10.1016/j.jcis.2011.07.017

[2] Siracusa V. (2012) Food packaging permeability behaviour: A report. Int. J. of Polym. Sci., 1-11. https://doi.org/10.1155/2012/302029

[3] Badmus AA, Gauri S, Ali NI, Gomes C. (2015) Mechanical stabilty of biobased food packaging materials. Food Sci. and Quality Management, 39: 41-48. 
[4] Xu X, Jayaraman K, Morin C, PecqueuxN. (2008) Life cycle assess of wood-fibrereinforced polypropylene composites. J of Mater. Processing Tech., 198: 168-177. https://doi.org/10.1016/j.jmatprotec.2007.06.087

[5] ISO, 2006a. ISO 14040: Environmental management - life cycle asses. - princ. and framew. Int Organization for Standardization, Genève, Switzerland.

[6] ISO, 2006b. ISO 14044: Environmental management - life cycle assess. - princ. and framew. Int. Organization for Standardization, Genève, Switzerland.

[7] Subramaniam V, May CY, Muhammad H, Hashim Z, Tan YA, Wei PC. (2010) Life cycle assess.of the production of crude palm oil (part 3). J. of Oil Palm Research, 22: 895-903.

[8] Schmidt JH. (2010) Comparative life cycle assess. of rapeseed oil and palm oil. The Int J. of Life Cycle Assess., 15: 183-197.

[9] Flynn HC, Canals LMI, Keller E, King H, Sim S, Hastings A, Smith P. (2012) Quantifying global greenhouse gas emissions from land-use change for crop production. Global Change Biology, 18: 1622-1635. https://doi.org/10.1111/j.1365-2486.2011.02618.x

[10] Choo YM, Muhamad H, Hashim Z, Subramaniam V, Puah CW, Tan Y. (2011) Determination of GHG contributions by subsystems in the oil palm supply chain using the LCA approach. The Int. J. of Life Cycle Assess., 16: 669-681.

[11] Vink ETH, Davies S. (2015). Life cycle inventory and impact assessment data for 2014 Ingeo $^{\mathrm{TM}}$ polylactide production. Industrial Biotechnology, 11: 167-180. https://doi.org/10.1089/ind.2015.0003

[12] Jusoh ER, Ismail MH, Abdullah LC, Robiah Y, Rahman WAWA. (2012) Crude palm oil as a bioadditive in polypropylene blown films. Bioresources, 7: 859-867.

[13] Sanyang ML, Sapuan SM, Jawaid M, Ishak MR, Sahari J. (2016) Effect of plasticizer type and concentration on physical properties of biodegradable films based on sugar palm (Arenga pinnata) starch for food packaging. J. of Food Sci. and Tech., 53: 326-336.

[14] Zaid SM, Myeda NE, Mahyuddin N, Sulaiman R. (2015) Malaysia's rising GHG emissions and carbon 'lock-in' risk : A review of Malaysian building sector legislation and policy. J. of Surv., Construction and Property, 6: 1-1.

[15] Abdullah WSW, Osman M, Ab Kadir MZA, Verayiah R. (2019) The Potential and Status of Renewable Energy Development in Malaysia. Energies, 12(2): 2437. https://doi.org/10.3390/en12122437

[16] Samsudin MSN, Rahman MM, Wahid MA. (2016) Power generation sources in Malaysia: Status and prospects for sustainable development. J. of Adv. Review on Sci. Research, 25: 11-28.

[17] Jungbluth N. (2006) Comparison of the environmental impact of tap water vs. bottled mineral water. Uster, Switzerland: Swiss Gas and Water Association Bull.

[18] Hervy M, Evangelisti S, Lettieri P, Lee KY. (2015) Life cycle assess. of nanocellulosereinforced advanced fibre composites. Composites Sci. and Tech., 118: 154-162. https://doi.org/10.1016/j.compscitech.2015.08.024

[19] Ortiz-Reyes E, Anex RP. (2018) A life cycle impact assess. method for freshw. eutrophication due to the transp. of phosphorus from agricultural production. J. of Cleaner Production, 177: 474-482.

[20] de Jonge VN, Elliott M. (2001) Eutrophication. Encyclopedia of Ocean Sciences, 2: 852870.

[21] La Rosa AD, Recca G, Summerscales J, Latteri A, Cozzo G, Cicala G. (2014) Bio-based versus traditional polymer composites. A life cycle assessment perspective. J. of Cleaner Production, 74: 135-144. https://doi.org/10.1016/j.jclepro.2014.03.017 